\section{MINE RESCUE TELEPHONE}

$\mathrm{M}^{\mathrm{n}}$

R. R. C. WOODS, of the Ericsson Telephones,

Ltd., London, communicates a description of a mine rescue telephone to the Ericsson Review of 1939 (No. 2). The Coal Mines Regulations require owners of mines, to which the regulations apply, to make definite provision for rescue work in mines after an explosion, fire or other accident. Telephone communication between the rescue brigade and its base is of great importance. Ericsson Telephones, Ltd., in collaboration with the Mines Department Testing Station, have constructed a mine rescue telephone which was officially tested last year, after which the production was immediately undertaken.

When a rescue corps is called to a mine, a base is immediately established in fresh air but as near as possible to the zone where the air is so foul as to be unbreathable. As the team of from eight to five men will be wearing breathing apparatus, speech is impracticable and communication has to be established by other means. Uniform codes of signals are prescribed, one for use between members of a brigade, for which each man carries a bulb hooter, and one for electric signalling. While the existing mine telephone system may provide for the telephone communication between the rescue corps and the base, it cannot be depended on and it would rarely prove convenient, speech not being practicable owing to the breathing apparatus, both of which are vital factors in such an apparatus, which only comes into use in severe conditions.

The mine rescue apparatus eonstructed by Ericsson's consists of two units, a base station and an advance station, connected continuously by a light but tough cable. In the constructional features of the design, particular attention has been paid to strength and low weight.

Signals in both directions are effected by a buzzer, using a special code. The note is distinct and penetrating, the high frequency avoiding any chance of confusion with other noises. In addition, the base party can speak to the advance party, both speech and signals being received on the loud-speaker at the advance station unit. After much consideration it was decided to limit to key signals only communications from the advanced party. If both-way speech were provided, the additional equipment would appreciably reduce the mobility of the advance party.

The base station unit is about $24 \mathrm{~cm}$. square with a depth of $16 \mathrm{~cm}$. On the front of it there is fitted a sensitive transmitter, a small loud-speaking receiver and a high-frequency buzzer. When the keys are in their normal position, the loud-speaking receiver is connected directly to the trailing cable and hence to the advance station unit. Any signal sent out by the advance party is thus immediately reproduced by this receiver. The batteries are of the ordinary cycle lamp type so that replacements are readily obtainable. Battery voltages are 6 and 3 volts respectively for the use of the base and advance party units.

Safe operation in dangerous atmospheres is a feature of this system. If during rescue operations it is desired to extend beyond the first cable length, a further advance party instrument can be connected by a simple plug and the circuit transferred from the first to the second unit.

\section{SEVENTY YEARS AGO}

\author{
NATURE, vol. I, February 1o, 1870
}

\section{The Royal Commission on Science}

"The Council of the British Association for the Advancement of Science was received on Friday last by Earl de Grey, Lord President of the Council, as a deputation to urge on the Government the issuing of a Royal Commission to inquire into the state of Science in England.

"The main points for a Royal Commission to throw light upon are these. First, is it right that science should be aided by the State ? Secondly, is the aid now given exactly what is needed-neither too much nor too little? Thirdly, the degree and direction in which science should become a State business having been settled, what will be the best organisation for the purpose? Not one of these points has ever yet been thoroughly considered in England."

\section{Microscopical Investigation of Meteorites}

Prof. N. S. Maskelyne, of the British Museum, provided a full abstract of his recent paper on this subject presented to the Royal Society. Transparent sections of small fragments cut from meteorites were studied under the microscope. They showed that "a meteorite has passed through changes and that it has had a history of which some of the facts are written in legible characters on the meteorite itself and, one finds, that it is not difficult roughly to classify meteorites according to the variety of their structure. One also recognises constantly recurring minerals ; but the method affords no means of determining what these are". The chief use of the microscope was as a means of sorting out the various minerals from "the bruised débris of a part of the meteorite", investigating each by the goniometer and by analysis, "and finally returning to the section to identify the actual minerals present".

\section{The Work of the Sea}

IN an article by C. W. Whitaker, M. Quenault is quoted as concluding, with regard to the depression of the land: "One gathers from all these evidences, that the movement, since the eighth century, has been about two metres a century. If it continues at the same rate for ten centuries more, the peninsula of Cotentin will be an island and all the ports of La Manche will be destroyed. Some centuries later and Paris will be a seaport, waiting only to be submerged in a score of centuries. Thus in a period, less than half as long as that during which the pyramids of Egypt have braved the ravages of time, Paris itself-if it is not burned down during one of the revolutions of its inhabitants, as amiable and spiritual as they are inconsistent-Paris will probably be engulphed in the A.tlantic, a master before whom the intractable Parisian must haul down his flag. Let him take warning !'

WITH reference to the "situation" at the Paris Observatory [see NATURE of February 3, 1939, p. 198], the action "of the French Government has been of the promptest and M. Le Verrier is no longer Director. This step indicates very clearly - too clearly we fearthe strength of the case put before the Minister of Public Instruction. . . . The document was signed by Villarceau, Marié-Davy, Wolf and Loewy. .. . 
It is to be sincerely hoped that M. Le Verrier may be able yet to do service to astronomy, in some other capacity, some position where his great talents alone will be called into play."

"A NEW office has been constituted under the Public Works Department and Mr. Douglas Galton, C.B., F.R.S., has been appointed to it with the title of Director of Works and Buildings. We may congratulate ourselves that our public building will be looked after by one so eminently qualified by his high scientific attainments and great experience in such matters."

M. Vérard de Sainte-Anne read a memoir before the Paris Academy of Sciences on a project for establishing communication between France and England. The author proposed the establishment of a railway bridge, either open or tubular, across the Straits of Dover.

\section{APPOINTMENTS VACANT}

Applicarions are invited for the following appointments on or before the dates mentioned

Commissioned ORdnance MEchanical EngINEkRs in the Indian Army Ordnance Corps-The Secretary, Military Department, India Director for the British Institute in Milan--The British Council, 3 Hanover Street, W.I (quoting 'Milan') (February 15).

RESEARCh OFFICER for Bacteriological work--The Secretary, Agricultural Research Council, 6a Dean's Yard, Westminster, S.W.1 (March 31). RADIO ENGINEERS by the Royal Army Ordnance Corps-The
Under-Secretary of State (A.G.9), War Office, Hobart House, Grosvenor Place, S.W.1.

Mechanical and Adtomobile Englneers by the Royal Army Ordnance Corps -The Under-Secretary of State (A.G.9), War Office, Hobart House, Grosvenor Place, S.W.1.

ENGINEER AND SHIP SURVEYoR for the Department of the SurveyorGeneral of Ships, Straits Settlements-The Crown Agents for the Colonies, 4 Millbank, S.W.1 (quoting M/9066).

TeMporary Forecasters, Grade II (Male), in the Meteorological Q.A., Air Ministry, Adastral House, Kingsway, W.C.2.

\section{REPORTS AND OTHER PUBLICATIONS}

(not included in the monthly Books Supplement)

\section{Great Britain and Ireland} Department of Scientific and Industrial Research. Report of the
Road Research Board, with the Report of the Director of Road Research, for the Year ended 31st March 1939. Pp. viii $+172+15$
plates. (London: H.M. Stationery Office.)
38. 6d. net. plates. (London: H.M. Stationery Office.) 3s. 6d. net.
Department of Scientific and Industrial Research: Water Pollution Research. Summary of Current Literature. Vol. 13, No. 1, January 1940, Abstracts Nos. 1-137. Pp. iv +36. (London: H.M. Stationery
[ 241

University of Liverpool: Social Science Department, Statistics Division. The Economic Status of Coloured Families in the Port of 18. net.

Medical Research Council. Special Report Series, No. 236 : Medical Uses of Radium; Summary of Reports from Research Centres for
1938. Pp. 49. (London: H.M. Stationery Office.) 18. net. [291

1938. Pp. 49. (London : H.M. Stationery Office.) 18. net. [291
Ministry of Health. Memorandum on the Production of Artificial Immunity against Diphtheria. (Memo. 170 Med.) Revised edition. Pp. 8. (London: H.M. Stationery Office.) 1d. net. [291
[Let.

\section{Other Countries}

Bernice P. Bishop Museum. Bulletin 142: Marquesan Insects, 3. (Pacific Entomological Survey, Publication 8.) Pp. v +220. Bulletin 159: Review of the Fauna of the Marquesas Islands and Discussion of its Origin. By A. M. Adamson. (Pacific Entomological Survey, Publication 10.) Pp. ii + 94. Bulletin No. 163: Archaeology of Mangareva and neighboring Atolls. By Kenneth P. Emory. Pp. 76+6 plates. Bulletin 164: Report of the Director for 1938. By Peter H. Buck (Te Rangi Hiroa). Pp. 32 . Index to Pacific Entomological Survey Publications. (Bulletins 98, 113, 114, 142.) Pp. 36. (Honolulu
Bernice P. Bishop Museum. Occasional Papers. Vol. 14, No. 14 : Fouling Organisms in Hawaii. By Charles Howard Edmondson and William Marcus Ingram. Pp. 251-300 (9 plates). Vol. 14, No. 15: Revision of the Fijian Ottistirini (Coleoptera, Curculionidae). By
Elwood C. Zimmerman. Pp. 301-312. Vol. 14, No. 16: A New Species of Byttneria from Mangareva. By E. D. Merrill. Pp. $313-316$. Vol. 14, No. 17: The Genus Phanerostethus in Fiji (Coleoptera, Curculionidae). By Elwood C. Zimmerman. Pp. 317-322. Vol. 14, No. 18: Cypraeidae from Makatea Island, Tuamotu Archipelago. No. 18: Cypraeidae from Makatea Island, Tuamotu Archipelago.
By William M. Ingram. Pp. 323-326. Vol. 14, No. 19: Endemic By William M. Ingram. Pp. 323-326. Vol. 14, No. 19: Endemic
Hawaiian Cowries. By William M. Ingram. Pp. 327-334. Vol. 14, Hawailian Cowries. By William M. Ingram. Pp. 327-334. Vol. 14, No. 20 : Preliminary Revision of the Fijian Baridinae (Coleoptera,
Curculionidae). By Elwood C. Zimmerman. Pp. 335-348. Vol. 14, No, 21: Santalum ellipticum, a Restatement of Gaudichaud's Species. No, 21 : Santalum ellipticum, a Restatement of Gaudichaud's Species.
By Frank E. Egler. Pp. 349-358. Vol. 15, No. 1: New Hawaiian By Frank E. Egler. Pp. 349-358. Vol. 15, No. 1 : New Hawaiian flora Group. By Harold St. John. (Hawaiian Plant Studies, 6.).Pp. 20 (6 plates). Vol. 15, No. 2 : New Hawaiian Lobeliaceae. By Harold St. John. (Hawaiian Plant Studies, 7.) Pp. 21-36 (7 plates). Vol. 15, No. 3: Notes on Polynesian Grasses. By F. R. Fosberg. Pp. 37-48. Vol. 15, No. 4 : Taxonomy of the Hawailian Genus Broussaisia (Saxi-
fragaceae). By F. Raymond Fosberg. Pp. 49-60. Vol. 15, No. 5: Bees from the Caroline and Palau Islands and Yap (Hymenoptera, Apoidea). By T. D. A. Cockerell. Pp. 61-66. Vol. 15, No.6: Reports on Fossil Mollusca of Molokai and Maui. By Jens Mathias Ostergaard. Pp. 67-78. Vol. 15, No. 7: New or Interesting Ferns from Micronesia, Fiji and Samoa, By E. B. Copeland. Pp. 79-92. Vol. 15, No. 8: Supplement to the Manual of Hawaian Mosses. By Edwin B. Bastram. Pp. 93-108. Vol. 15, No. 9: The Genus Ficus in the Samoan Islands. By V. S. Summerhayes. Pp. 109-118. Vol. 15, No. 10: Diospyros ferrea (Ebenaceae) in Hawaii. By F. R. Fosberg. Pp. 119-132. Vol. 15, No. 11: Studies of the Pacific Bees in the Collection of Bishop Museum (Hymenoptera, Apoidea). By T. D. A. Cockerell. garevan Expedition. By Dudley Moulton. Pp. 141-148. Vol. 15, No. 13: The Canoe Making Profession of Ancient Times. Translated by Mary Kawena Pukui, Edited and annotated by Kenneth P. Emory. Pp. 149-160. Vol. 15, No. 14: A New Species of Zoraptera from Bishop Museum.)

Smithsonian Miscellaneous Collections. Vol. 98, No. 25: List of the Fishes taken on the Presidential Cruise of 1938. By Waldo $\mathrm{L}$. Schmitt and Leonard P. Schultz. (Publication 3551.) Pp. ii +10 .
(Washington, D.C.: Smithsonian Institution.)
$[231$ (Washington, D.C. : Smithsonian Institution.)
Scientifle Publications of the Cleveland Museum of Natural History. vol. 4, No 2: Birds of Eastern Newfoundland. By John W. Aldrich and David C. Nutt. Pp. 13-42. Vol. 5, No. 4: The Quadrat Method of Studying Small Mammal Populations. By B. P. Bole, Jr. Pp. 15-78. (Cleveland, Ohio : Cleveland Museum of Natural History.) [231

Division of Fish and Game of California : Bureau of Marine Fisheries. Fish Bulletin No. 54: The Fishes of the Family Sciaenidae (Croakers) of California. By Tage Skogsberg. Pp. 62. Fish Bulletin No. 55: 1937. By Richard B. Tibby. Pp. 36. (Terminal Island, Calif. : State 1937. By Richard B. Tibby. Pp. 36. (Terminal Island, Calif. : State
Fisheries Laboratory.)
[241 Proceedings of the California Academy of Sciences, Fourth Series. Vol. 23, No. 25: Notes on some Forms of Oreohelix strigosa. By G. Dallas Hanna and Allyn G. Smith. Pp. 381-392+plates 33-36. Vol. 23, No. 26: Notes on a Collection of Reptiles and Amphibians plates 37-38. Vol. 23, No. 27. A New Genus and Species of Marine Ostracods from South Georgia. By Tage Skogsberg. Pp. 415-426. Vol. 23, No. 28: The Bees of the Southern California Islands. By Prof. T. D. A. Cockerell. Pp. 427-436. (San Francisco, Calif. : California Academy of Sciences.)

Annual Report of the Board of Regents of the Smithsonian Institution showing the Operations, Expenditures and Condition of the Institution for the Year ended June 30, 1938. (Publication 3491.) Pp. xiii +608 .

$[251$

U.S. Department of the Interior : Office of Education. Bulletin, 1939, No. 2: Accredited Secondary Schools in the United States. By Margaret J. S. Carr. Pp. v +180 . (Washington, D.C. : Government
[251

$[251$

Om Uppflnningen av den Akromatiska och Aplanatiska Linsen: med Särskild Hänsyn till Samuel Klingenstiernas Insats. Av N. V. E. Nordenmark och Johan Nordström. (Särtryck ur Lychnos 1938 och 1939.) With an English Summary. Pp. 52+313-384. (Uppsala :
[291

U.S. Department of Agriculture. Circular No. 551: The Basis for Treatment of Products where Fruittlies are involved as a Condition Treatment of Products where Fruitties are involved as a condition for Entry into the United States. By A. C. Baker. Pp. 8. (Wash-
ington, D.C.: Government Printing Office.) 5 cents.

Report of the Twenty-fourth Meeting of the Australian and New Zealand Association for the Advancement of Science, Canberra Meeting, January 1939. Honorary Editor: Margaret Walkom. P1. $1+455$.
[291 Field Museum of Natural History. Botanical Series, Vol. 20, No. 2 : Francis Wolle's Filamentous Myxophycer. By Francis Drouet. (Publication 460) Pp 15-64, 40 cents Botanical Series, Vol. 20, Fu The Planktonic Freshwater Species of Microcystis. By Francis Drouet and William A. Daily. (Publication 461.) Pp. 65-84. 15 cents.
(Chicago: Field Museum of Natural History.)

Mémoires de la Société de Physique et d'Histoire naturelle de Gene Vol 41, Fascicule 5: Etudes sur la partie occidentale du Geneve Par Warner Lüdi. Pp. 467-498. (Genève : Georg et Cie.) 3 francs. [291 Palæontologia Indica. New Series, Vol. 29, Memoir No. 2: The Fossil Charophyta of the Decean Inter-Trappeans near Rajahmundry (India). By K. Sripada Rao and S. R. Narayana Rao. Pp. iv $+14+3$ plates. (Calcutta: Geological Survey of India.) 1.12 rupees;
[301 